\title{
Revelation, Literature, and Community in Late Antiquity
}

\section{Ed. by Philippa Townsend and Moulie Vidas}

[Offenbarung, Literatur und Gemeinde in der Spätantike.]

Veröffentlicht auf Englisch.

Das vorliegende Werk entstand aus einer Konferenz führender Wissenschaftler auf dem Gebiet der antiken Religionen.

Revelation, Literature, and Community in Late Antiquity

Edited by PHILIPPA TOWNSEND and MOULIE VIDAS Ansprüche auf eine göttliche Offenbarung sind nicht einfach ein allgemeiner Topos in antiken religiösen Texten: sie bestimmen oft die Struktur dieser Texte und der Gemeinden, die diese hervorbringen. Die Autoren untersuchen die literarischen und sozialen Funktionen der Offenbarung in der Spätantike vom rabbinischen Judentum bis zum frühen Islam und tragen somit zum Verständnis des Phänomens der Offenbarung und des Studiums der großen Transformationen, Interaktionen und typischen Spannungen dieser Zeit bei.

Philippa Townsend Born 1975; degrees in Classics from Cambridge University and University College London, in Religion from Harvard University and Princeton University; PhD from Princeton in the Religions of Late Antiquity; currently Assistant Professor of Philosophy and Religion at Ursinus College, Pennsylvania.

Moulie Vidas Born 1983; Associate Professor of Religion at Princeton University

\section{Jetzt bestellen:}

https://mohrsiebeck.com/buch/revelation-literature-and-community-in-late-antiquity-9783161518591?no_cache=1 order@mohrsiebeck.com

Telefon: +49 (0)7071-923-17

Telefax: $+49(0) 7071-51104$ 